\title{
Dossier
}

\section{Animals in anthropology}

\author{
Jean Segata \\ Graduate Program in Social Anthropology, Universidade Federal do Rio Grande do Sul, \\ Porto Alegre/RS, Brazil.
}

\section{Bernardo Lewgoy}

Graduate Program in Social Anthropology, Universidade Federal do Rio Grande do Sul, Porto Alegre/RS, Brazil.

Animals are not new to anthropology. Since the early days of the discipline they appear in rituals, classifications and symbols. Animals are hunted, raised, domesticated, eaten, feared and venerated. Of course anthropology is generically defined as the discipline that studies "man", and it is thus common that animals only appear in a supporting role: they are part of the scenery described, assistants in activities or a means to help understand how humans think and organize themselves in the world. One of the many consequences of this attitude was to authenticate the generalized idea that animals are seen as resources of all sorts of types, given that they only appear as part of ecosystems - cultures or societies - which are anthropically centered. Animals have thus been relegated in the traditional anthropological project to figurative functional or mediating roles in contrast to the majesty of human agency. ${ }^{1}$ To some degree, this dossier is part of an agenda that is critical of this more traditional posture, and accompanies a set of debates that have been expanding in the discipline and that shift animals from their position as simple appendixes of humans or as elements in the environment, to position them in the foreground of ethnographies, making more visible how the lives of animals and humans interact and are co-produced.

In this critical direction, Rebeca Cassidy (2007), when discussing the literature about domestication, makes explicit references to how the anthropological tradition can be understood in terms of humans' relationship with animals (and with plants). For Cassidy, the domestication of animals and the development of agriculture were treated in the discipline in terms that are similar to the explanation of the passage from savagery to barbarity and from the affirmation of civilization, to the defeat of a feminine mode of the world, and the consolidation of private property. This anthropological posture mirrored zoological thinking, which emphasized human control over plants, animals and "primitive" peoples and incorporated

\footnotetext{
1 The famous controversy between Marvin Harris (1976) and Claude Lévi-Strauss (1983a, 1983b) emblematically illustrates this tendency. In Harris' cultural ecology, societies were understood as a cultural adaptation to pressures from their natural environments. In Levi-Strauss's structuralism, we find the idea that mythic thinking organizes certain salient elements of the empiric world in signifying systems. Thus, in a non-exclusive reduction, nature, including animals, in both cases, are an objectifiable externality. For Harris they are inscribed in a naturalistic semantic (animals are good for the environment or good for evolving) and in Lévi-Strauss' structural semiotic they are good for thinking. A significant change in the anthropological perspective on animals began to take shape with the work of Philippe Descola, in particular in the realm of his anthropology of nature. Dscola indicates that (i) nature cannot be considered as a universal condition (or as a category) upon which is established cultural discontinuities and (ii) it cannot be understood, in general, as an external ontological domain that is distinct from the world of humans. The forest is not a prosaic place - a source of food or of mental categories - but "the stage of a subtle sociability [...]. What we call nature here is not an object that must be socialized, but the subject of a social relation" (Descola 1996:246-7). In later work Descola (2005) systematizes what he calls modes of identification and relation to reposition the debate between nature and culture in terms of continuities and discontinuities between the living. See also his well developed criticism of the concept of nature in Lévi-Strauss (Descola, 2011).
} 
them to the "civilized" world for purposes of exploitation. For Cassidy (2007), more recent anthropology has substituted the unidirectional and progressive history of human relations with animals for a more incomplete and hesitant version in which the experience of sheep and goats, for example, are confronted with the more ambiguous stories of microbes and weeds. The emphasis on the mutual interaction between humans and non-human species that reposition animals in the anthropological debate coincides with a time of reconfiguration for the discipline since the 1970s. The publication of important works such as Anthropology and the Colonial Encounter, edited by Talal Asad (1973) and Women, Culture and Society, edited by Michele Rosaldo and Louise Lamphere (1974), are emblematic of the construction of new routes in anthropology, due to their crucial role in decentering ethnocentric and androcentric premises that have long been deeply rooted in the discipline. It is in this intellectual context that the seminal philosophical essay Animal Liberation was published by Peter Singer (1975), which in addition to being a point of inflection in animalist thinking, inaugurated the broad interdisciplinary field of Animal Studies. It became central in the reformulation of the ethical and political horizon of the problem of animals in the West in the late twentieth century, converging with the rising post-colonial feminist struggles. Since then, under the influences of these debates, anthropological thinking has become less white, less male and less anthropocentric.

Animal studies is a vast interdisciplinary field that in addition to anthropology includes sociology, history, philosophy and literature. It is subdivided and disputed by fields of interest such as animal rights, which advocates the moral recognition of animals and their conditions as subjects with rights on an equality with humans; anthropozoology, which is concerned with the biological ties between different animal species, including humans; ethology, which focuses on the study of their behaviors; and human-animal studies, which focuses on the social relations between animals and humans (Demello, 2012). ${ }^{2}$ This broad movement is a response to an epistemological and moral shift in the human-animal relationship, which forms the base of the studies that compose this dossier. But, what is an animal and what does it do in anthropology?

Ingold (1994) helps to locate the position of animals in the discipline based on a philosophical question of broad scope in the West - the definition of the human. By asking what makes a human a human? Ingold suggests that what we understand as characteristic of humanity is located to a large degree in the negation of animality, which is always treated as deficient in relation to all that we humans supposedly have - including language, reason, or moral conscience. The critical point is an anthropomorphism that, on one hand, is characterized culturalistically, given that it supposes that only humans have a capacity for symbolization and differentiation between each other through will and consciousness. On the other hand, it appears in the naturalist definition of man as an animal species, whose supposed difference resides precisely in the fact that he stands out from all the other animals, which are treated as essentially equal and destined to follow genetic programming. In the final analysis, it is a question of singularization. For this reason it is not difficult to understand how we are able to look at other humans and see them, even if they are equal as a species, as perceptibly or completely different from each other, given that we attribute to each one of us different and unique capacities of variation, inherent to humanity. This is not a question of types, nor of essences, Ingold warns (1994): it first involves the capacity of singularization that we attribute to ourselves. However, the difficult question is why

\footnotetext{
2 In human-animal studies the lives of humans and animals interconnect - they are relatives, friends, significant alterities. It is in this field, in particular, but not exclusively, that we position anthropology. On this basis, it is understood that animals are socially constructed and for this reason are present in a wide variety of contexts, as a form of thinking, interacting or serving human needs (Demello 2012). For good field sketches, in addition to Demello (2012), see also Flynn (2008), Taylor \& Signal (2011) and Taylor (2013). This dossier focuses in particular on anthropological production on the theme and although it does not have a well-defined agenda in the discipline, works such as that of Vialles (1987), Ingold (1988), Willis (1990), Digard (1990, 1999), Bernardina (2006) and Keck (2010) guide many researchers interested in the field. Meanwhile, Hurn (2012) offers an important overview of the human-animal relationship in anthropology.
} 
we do not perceive cats or dogs or any other animals, especially those more distant from conviviality with humans, to be distinct from each other. We attribute to them a homogeneity specific to an essential biological programming - that of a species - whose small differences fall within a limited possible range of variation in genetic arrangements, which we call race. In other words, non-human animals are, for us, naturally biological, while humans are biological and something more. The critical point, is the recalcitrant idea of a human exceptionality. ${ }^{3}$

On the other hand, there is a second issue that arises from this first: what makes a human being a being? In response, Ingold (1994) suggests a shift from ontology to ontogenesis. He does not speak of human beings, but of human becomings (Ingold 1994; Descola \& Ingold 2014). He affirms that ontology is part of an ethnocentric project, which as can be expected from "philosophers of philosophy", results from considering texts from that discipline without considering the world. For this reason, lines occupy an important place in his lexicon, given that they allow thinking in incessant crossings, in a wide variety of webs, in an insistence to the devir. In other terms, the composition of worlds cannot be considered as a task of representing life based on beings as if they preexisted (ontology). It must be based on their production in a continuous event in their environment and in their entanglements (ontogenesis). Therefore, and taking another route, more than a definition of borders between humans and animals, anthropology has been interested in the joint forms of conviviality. In general lines, this is the position defended in the work of Carlos Sautchuk, Eating (with) piranhas: an untamed approach to domestication, which brilliantly opens this dossier. Based on an instigating ethnography among fishermen in the Amazon estuary, the author shows us how the proximity between the fishermen and the piranhas can be understood as a type of conviviality related to the production of a shared environment. This is shown in the presence of children in fishing activity - the development of technical abilities requires a type of plunge into the world - the "gestures" of the fish, the ondulations of the water, the moment of capture - require an interlinking that causes learning to be conducted in terms of an ontogenesis.

In the early 196os, a seminal text by Haudricourt (2013), entitled Domestication des animaux, culture des plantes et traitement d'autrui, offered an alternative vision to the unilateral model of exploitation of nature and animals, emphasizing the symbolic and relational character of the domestication process. Haudricourt was a disciple of Marcel Mauss and inherited some of the principle ideas developed by this master in his celebrated work Les techniques du corps, such as traditional/social character of technique. That is, it cannot be reduced to the condition of the biology or psychology of man, nor by the determinations of his environment. Technique is thus learned and transmitted by means of prestigious and collective imitation. Another influence from Mauss concerns how Haudricourt observes technical innovations. This involves how domestication, culture, nature and body are articulated within each culture (Bechelany 2012). In this sense, Haudricourt emphasizes how relations with plants, animals and things express the development and socialization of the human being, much more than when attention is focused only on humans or on technique itself. ${ }^{4}$ In Haudricourt's classic text (2013), the two examples presented - the yam and the sheep - reflect two types of mentalities. On one hand is the farmer from the Far East who operates by means of

3 For a broader critical review of this point, see Lewgoy and Segata (forthcoming). Also about this issue, the finding is interesting that in the universe of veterinary medicine studied by Segata $(2012 ; 2015 \mathrm{a}, 2015 \mathrm{~b})$, cats with renal problems, dogs that are constipated, obese or have cancer or depression, are diagnosed and treated with the biomedicine used for humans. To this corresponds the provocation that if dogs and cats are "other humans" who share our lifestyles, our eating habits or our diseases, we would thus be "other animals" because we share with them the same organic properties. This humanization of animals appears to be assured by our animality, and vice versa.

4 Most of these ideas were in the volume Des gestes aux techniques: essai sur les techniques dans les sociétés pré-machinistes, where the emphasis was not on technique as something abstract or the technical object as an isolated entity but on the gesture that it involved, which he called the technical act. His analysis is focused on the relations lashed together by a subject, which is different on one hand, from instrumentalism, which focuses on external purposes, and on the other, from utilitarianism, which concentrates on the observation of the exclusive product of technique. See Bechelany's important review (2012). 
indirect negative action when dealing with others (plants and animals). On the other hand is the European/ Western pastor who is guided by positive direct action, which refers to the mode of governamentality, in which a distinct individual (man, pastor, as sovereign) leads others (sheep, society). Overlapping materials from various contexts and epochs, Haudricourt (2013) show how elements such as taking walks, or the rigidity or lightness of certain human gestures, were produced in co-participation with animals that were hunted and domesticated, or with plants that require certain care for their cultivation. ${ }^{5}$

The recent proposal for a "multispecies ethnography" has various points of contact with Haudridourt's (2013) reflection, especially concerning the emphasis on relationality. This instigating proposal considers the importance of including and symmetrizing creatures that had been marginalized in anthropological thinking "as part of the landscape, as food for human beings or as symbols - [which] become shifted to the foreground in recent ethnographies" (Kirksey \& Helmreich 2010:545-546). Thus, "animals, plants, funguses and microbes that were customarily confined to an anthropological inventory of the 'bare life', began to appear together with humans in the sphere of the bios, with legible biographies and political life" (emphasis ours). Multispecies ethnographies expand the scope of interest of the field of human-animal relations by including a wide variety of organisms as active builders of shared worlds. At the same time, they support an analytical gain by shifting the line of demarcation between humans and animals, to focus on the encounter, the sharing and the crossing of these lives. In this way, the question arises: how can anthropology pay attention to the zones of contact and rupture of the multitudes of creative agents whose ecological niches are co-produced along with humans? Recent ethnographies have shown, for example, how microbes are social agents on earth, in the sea, in food (Tsing 2015; Helmreich, 2013; Haraway 2008). They thus reveal relations with biopolitics, biocapital or biodiversity (according to Michel Foucault, the optimization, coercion and control of biology in favor of regimes of domination of life or how nature has been modified in favor of biopolitics apud Rabinow 1999). How is it that anthropology can follow (in the sense of a multispecies ethnography) animals, invasive plants or microbes, given that they act in different environments? How can humans and animals be linked, through politics or ecologies?

Another important classic theme of anthropology that has been revisited in the debate of the sphere of human-animal relations is that of kinship. Nerissa Russell (2007) suggests that social anthropologists can profitably increase their understanding of the domestication of animals by articulating it as the theoretical domain of kinship. Appropriating the contributions of recent studies and criticisms of kinship in anthropology, from authors such as Marilyn Strathern, Janet Carsten, Sarah Franklin and Susan McKinnon, Russell (2007) calls attention to a combination of biological and social relations involved in the way of thinking of domestication, arguing that domestic animals also occupy the frontiers of being, nature and culture. Combining elements of archeology and anthropology, Russell proposes thinking of the domestication of animals as a type of classification, a social act which invokes intimate and unequal relations between animals and people and among relatives. She suggests that this overlapping of prominent questions can be more evident in the phenomenon of bride purchasing, a process that often implies both relations between people and between people and animals. Russell (2007) concludes by arguing that domestication can be better thought of as a varied set of practices with intentional and non-intentional consequences, which may or may not create biological changes in the animals themselves. These practices are better studied at certain times and places, because the meanings of terms and of the domesticated relations (such as that of relatives) will vary over time and space. Another important (and disturbing) issue raised by Russell (2007) concerns domestication as a relationship among relatives; in more precise terms, kinship with other species.

5 Once again, the work mentioned by Sautchuk is emblematic for thinking of the currentness of this debate, given that fishing, as the author highlights, presumes an involvement between man and fish, or in more explicit terms, requires a mutual domestication. At the same time, being configured as a model of predatory sociality, it reinforces in both a proximity that is consolidated through carnivorous exchanges. Fishing, as technique, shapes the fish and the man. 
For Russell, a new theory of kinship is based on at least two sources from classic approaches: a first impulse is queer theory, which affirms the validity of other types of families and relationships in addition to those that classically compose kinship structures. Another comes from scientific studies, in which scholars contemplate the implications of new biological technologies. In-vitro fertilization, cloning and transgenic chimeras create new types of relationships that in some way must be incorporated when considering kinship. Theoreticians such as Donna Haraway embrace this indetermination. Strathern (1992:16-17) observes that kinship represents a hybrid of different elements. Human kinship is considered as a fact of society rooted in facts of nature. We recognize people as being divided between those related by blood and those related by marriage, or that is, as the result of kinship or from a perspective of procreation. Nevertheless, the process of procreation, as such, is seen as belonging not to the domain of society, but to the domain of nature. Kinship thus connects the two domains and in this sense, it and domestication share some common characteristics. Both involve classification systems, which are in turn related to questions of power and affection. They are preferentially realized in the sphere of the family unit in the broad sense (domus). Like human social relations, they are mediated by kinship structures, they are also negotiated by means of domestic animals (through the interchange of animals, clientelistic relations based on loans of cattle, etc.). The two interconnect in dowries, through transactions like those made with cattle in many parts of Africa. The crossing and hybridization between biology and society create new challenges and associations and continue to help us to understand the human-animal relationship in close and distant contexts.

Also in favor of this general context of transformations in the debate about the human-animal relationship in anthropology, it should be mentioned that a recent colloquium in France addressed the emergence of this group of discussions under the idea of an animal shift in anthropology. The agenda included the recent conjunction between the advances of the life sciences and their approximations with ethology and cognition, the review of classic philosophical discussions about man and animals and the sensibilities following from recent protectionist movements. According to the presentation of the colloquium, 'jusqu'à quel point l'intérêt pour 'l'animal' contribue-t-il à la connaissance des animaux autant que des hommes en société, à la connaissance de la diversité et de la complexité de la cohabitation des vivants? Peut-il constituer un objet d'étude à part entière? Les approches méthodologiques sont-elles orientées, et si oui comment, par les formes d'engagement autour de ce qu'on appelle aujourd'hui "la question animale"? Débouchent-elles sur des positions métaphysiques qui articuleraient de façon nouvelle les formes du vivant". By questioning a certain lack of interest by the discipline for the "animal question", the shift that the Paris colloquium revealed is not reduced to explaining the interest of anthropology in animals, but their presence as a significant alterity. However, Digard (2012), an important thinker in this field, raised concerns about this movement. In a paper dedicated to criticizing some of the positions presented in the Paris colloquium, he questioned the paradoxical place and status of the human-animal relationship in the West: while some animals are consumed others are overprotected. For him, this is the case of an animalitarian phenomenon that supposes animalism as an ontology.

Animalism is a quite diffuse term. According to Digard (2012), it is used to address both the inclusion of animals in the human and social sciences, and in the case of ethnozoorarcheology, ethnosciences, the ethnology of pastors and gatherers, among others. In another form, it appears as a movement - the center of gravity of a type of animalitarian activism. Part of this movement began after World War II, with the economic reconstruction in which traditional, familiar and polyvalent husbandry gave way to concentrated, intensive and specialized processes. These changes altered the French way of life, and their

6 The complete program can be found at: <http://www.college-de-france.fr/media/philippe-descola/UPL23153_Tournant_animaliste_Animal_ Turn_11_06_22_24.pdf>. Accessed in November 2016. 
meat consumption rose from $50 \mathrm{~kg}$ per person per year in the 1950 s to nearly $100 \mathrm{~kg}$ in the $1980 \mathrm{os}$, after which it dropped to gokg. This effectively changed the relationship with animals in the context of husbandry, which became more impersonal and shaped by production pressures. Another question for Digard (2012) concerns the number of pet animals that has also surprisingly increased in France - reaching 60 million. They are now a part of the family - a cathartic solution to loneliness - something a middle class family must have. No expense is too high for the food and care of these pets, which has led to the appearance of many veterinary clinics. There is also an urbanization of the relationship - or that is, a distinction in terms of human-animal relationships that profoundly distinguishes it from the rural form. While dogs and cats appear in large numbers, pigs, rabbits, rats, lizards or snakes are also treated as pets. The appearance of new pets has become common, Digard (2012) mentions, such as horses, which are less frequently used as draft animals or for competitions. There has similarly been an increase in the number of documentaries in which "wild fauna", from sharks to bears or wolves, appear as innocent creatures that are threatened by man, who is demonized in the relationship. The issue is that the relationship with wild animals (which the author considers less wild because they are protected and handled by humans) has a symmetrical and inverse status than the relationship with pets. The relationship is symmetrical because neither has utility and it is inverse because pets embody a maximum of human intervention and are thus appreciated for proximity, while wild animals incarnate the idea of being free of human intervention. Man is seen as an externality to the natural environment. This difference is also noted in the French case by the gap found between pets and farm-raised animals - where the first are considered to be an elite form of animal while the second case involves the denunciation of exploitation. According to Digard (2012), the universe of animal protection in France is a nebulous of nearly 280 associations, some created in the mid nineteenth century. Nevertheless, it should be understood that the various emerging forms of animalitarianisms - like those of humanism are corollaries of Eurocentric philosophies and their generalizing formulas and for this reason the study of human-animal relations must be ethnographically situated.

The constitution in Brazil of the field known as "human-animal relations" does not precisely follow this disciplinary dynamic of Animal Studies. The reference is certainly present, but animals became significant based on particular questions within other fields, such as the anthropology of science (with its multiple analytical devices and experimental observation technologies, animal models, telemetry, and veterinary sciences etc.) or of indigenous ethnology (in which cougars, turtles, capybaras, birds and fish have a prominent presence in cosmology and mythology), in large- and small-scale husbandry, for mass production and for subsistence, and last but not least in the multiple and heterogeneous presence of animals in urban environments, in situations related to zoonoses, the pet market or animal protection. In addition to the individual works of Bevilacqua (2011, 2013, 2014), Segata (2012), Vander Velden (2012), Sá (2013) and Sussekind (2014), located in the continuum understood to exist between the "animalist shift" and "Amerindian ethnology", recent collections celebrate the appearance of the animal-subject in ethnography, substituting the ancient animal-object of representation and use. Emblematic examples of this are found in the works that compose the collection Parentes, Vitimas e Sujeitos [Relatives, Victims and Subjects], organized by Vander Velden \& Bevilaqua (2016), which to a large degree was inspired by ethnology, especially by specialists in the Arctic circle (Ingold 2000) and by Amazon scholars (Descola 2005; Erikson 2012; Fausto 2004).

Following the route blazed by this first generation of researchers, new works have appeared that emphasize animality as a theme of high interest in relation to the influences of globalization and science. This can be seen in the strategies of distinction in the breeding and production of cattle in Leal (2016); in the situation of wild boars that ignore borders and property lines presented by Sordi (2015); among the lab rats in Souza (2013) that challenge moral indifference and evoke the biopolitical tattooing of Giorgio 
Agamben and the ethics of Emmanuel Levinas; in the transnational mosquito that mobilizes biopolitical emergencies in studies by Segata (2016a, 2016b); in the dogs with leishmaniosis on Brazil's "triple frontier" with Paraguay and Argentine, addressed by Argentine anthropologist Andrea Mastrangelo (2016); and in the urban animal - a bastard child of this venerable line - which is treated as a child by middle class families, yet which as a victim is deserted at the metropolitan peripheries (Fudge 2014; Lewgoy, Sordi \& Pinto 2015). This second group, is in general dedicated to investigating animals in less exotic contexts than those commonly emphasized in the discipline, but which equally place anthropology in limit situations, by inserting themselves in the crossing of effects and influences of broad geopolitical, global and local trends, with highly complex urban and rural realities. ${ }^{7}$

In relation to Brazil it is also important to mention that the imminent expansion of the field is indicated by working groups and round table discussions at events such as the Reunião Brasileira de Antropologia [The Brazilian Anthropology Meeting]- RBA, Reunião Equatorial de Antropologia/Reunião de Antropólogos do Norte e Nordeste [The Equatorial Anthropology Meeting/Meeting of Anthropologists of the North and Northeast] REA-ABANNE, Reunião de Antropologia da Ciência e da Técnica [The Anthropology of Science and Technology Meeting] - REACT, Reunião de Antropologia do Mercossul [Anthropology Meeting of Mercosur] - RAM and Encontro Anual da Associação Nacional de Pós-Graduação e Pesquisa em Ciências Sociais [The Annual Meeting of the National Association of Graduate Studies and Research in the Social Sciences] - ANPOCS and research groups such as Espelho Animal [Animal Mirror] at the graduate program in social anthropology at UFRGS and thematic dossiers in journals such as the Anuário Antropológico (UnB), the Revista Anthropológicas (UFPE), the R@U (UFSCar), CADECS (UFES), as well as other forthcoming dossiers, such as that of Iluminuras (UFRGS), Vivência (UFRN) and Horizontes Antropológicos (UFRGS). Moreover, it is notable that in recent years theses and dissertations have been produced based on studies of this issue (Calmon de Oliveira 2006; Segata 2012; Matos 2012; Pastori 2012; Sordi 2013; Franco 2015; Teixeira 2015), some of which have been published, (Sá 2013; Vander Velden 2012; Süssekind 2014; Leal 2016). Therefore, it should be recognized that Brazilian anthropological production about the issue is emergent and pulled between various intellectual influences and styles (in a continuum between ethnology and urban anthropology, which is the source of its wealth). This is shaping a problematic that, despite the variety of publications, working groups and research projects, is consolidating this line of research in institutions and support agencies.

It should also be emphasized that authors such as Philippe Descola and Eduardo Viveiros de Castro are references with a constant presence in the field, particularly, in relation to the epistemological issues they raise. Animals have long been omnipresent in the daily life and mythology of the indigenous world, but upon following the more recent theories and recognizing the agency of non-human animals, ethnology became, alongside animalism, one of the strong inductors and matrixes of transformation of the humananimal connection in anthropology. This domain is represented in this dossier by the works of Vander Velden "Village Ornaments: Familiarization and pets as art(ifacts) in Amazonia" and by Arisi "Matis Animal Feasts: Minimal mimesis for social relations weaving”. Together with Bevilaqua, Vander Velden was one of the pioneers in the agencying of an intellectual and institutional locus for the encounter and dialog with researchers interested in human-animal relations. His study among the Karitiana, the source of the article published here, reveals the place of animals raised among this indigenous group, emphasizing the aesthetic of human-animal conviviality in houses and villages. Arisi shows the socio-cosmological role performed

\footnotetext{
7 For example, in a recent presentation of the issue of R@u - Revista de Antropologia da UFSCar, dedicated to plural animalities, which combined works of young Brazilian anthropologists with foreign interlocutors, Felipe Vander Velden (2015) emphasized the importance of reviving elements of symbolic anthropology (it can be helpful to think about those animals) along with recognition of the agency of animals. This revival of the theoretical heritage of symbolic anthropology is strategic for dealing with situations where animals arouse the native imagination and establish a relationship with other domains of social life, such as morality, politics, magic and kinship, indicating a more serene relationship with the "anguish of influence" in the sense used by Harold Bloom (1991).
} 
by animals at banquets where a relationship with different types of alterity is agencied by the projection of zoological classifications. The two works share an emphasis on the aesthetic dimensions of the indigenous relational universe, not a segmented dimension, as in the West, but a mode of collective being that, as Joana Overing affirms, is also a poetic.

It is also possible to perceive the interlinking of the various ethnographic contexts that form the scope of interest of the field of anthropology of human-animal relations in Brazil from the works of Natacha Leal, Flávia Rieth, Daniel Vaz Lima and Marília Floor Kosby, as well as those of Felipe Süssekind, who look at different rural universes of husbandry in rural Brazil. Focused on elite cattle auctions in the Minas Gerais city of Uberaba, in the study entitled About Zebus and Zebuzeiros: Value and price, influences and substances in elite cattle auctions, Natacha Leal analyzes the economic, political and symbolic relations among men and cattle that compete to produce products and intellectual capital in this species that is Brazil's leading animal export. Leal shows how cattle are much more than a good, but multidimensional and complex beings, which agency relations, knowledge, identities and representations. Meanwhile, in the study The Way of Life of the Brazilian Pampas: an ethnography of the Campeiros, Rieth, Lima \& Kosby operate in the register of heritage, investigating the relationship between humans and animals in the rich pampa culture of Rio Grande do Sul. Then, in Notes on the Bagual: Cattle raising, hunting and conservation in the Brazilian Pantanal, Süssekind analyzes cattle raising in the Pantanal of Mato Grosso and considers cattle as a key link in an articulation between ecology, economics and experimentation. He finds cattle are also the focus of various classification systems, based on contrasts between "tame" and "fierce" and "domestic" and "wild", pretexts he uses to discuss the modalities of practice in the human-animal relations in the region.

As a counterpoint, but equally immersed in the complex situations that the field has explored, is Andrea Osorio's study Sociabilities and Sensitivities: Recruitments in caring for homeless animals. Osorio interviewed people who protect animals to analyze their trajectories, dispositions and values. She shows that animal protection has various modalities of recruitment and participation, and that the conversion to the struggle is a heterogeneous and varied process, which takes form as a type of "high cost citizenship, which at times flerts with religious inclinations.

In another direction, addressing a quite controversial theme in the field of human-animal relations - is the work of Marcos Carvalho, Producing Chimeras: Lineages of rodents, laboratory scientists and the vicissitudes of animal experimentation. Considered as model animals that are constantly desubjectivated by the hegemonic discourse of official science, guinea pigs were discovered by veterinary science, by bioethics and by laws about the ethical use of animals. Beyond the focus on well-being, and the specific fascination of the anthropology of science for "non-humans" in laboratories (with their clocks, walls, smocks, clipboards, chemicals, surgical materials and instruments and test tubes) Marcos Carvalho asks in his ethnography about the singularity of guinea-pigs. Integrated with other work, like that of Souza (2013), Carvalho focuses on the relationship between humans and guinea pigs to go beyond a residual humanist tie, emphasizing the agency of these animals in the result of the experimental studies.

Finally, the dossier concludes with the graphic essay by Aina Azevedo and Sara Asu Shroer. The authors use graphic art to take an unprecedented look at falconry inspired by Tim Ingold's phenomenological anthropology. The impressionistic designs of Aina (who also illustrated the cover of this dossier) show the agency of the falcons and the falconers, as well as the role of climate, earth and air in the readings and dialogs between each other and the environment. The text's dissatisfaction with the traditional conventions of anthropology for considering the human-animal connection and the new routes offered to represent it is emblematic of the methodological, conceptual and poetic challenges that this volume modestly sought to bring together. 


\section{References}

ASAD, Talal. 1973. Anthropology and the colonial encounter. Ithaca: Cornell University Press.

BECHELANY, Fabiano. 2012. "Resenha de Des gestes aux techniques: essai sur les techniques dans les sociétés pré-machinistes (de Haudricourt, André-Georges)”. Anuário Antropológico, 2012(2): 247-251.

BERNARDINA, Sergio Dalla. 2006. L'éloquence des bêtes: quand l'homme parle des animaux. Paris: Métallié.

BEVILAQUA, Ciméa. 2011. "Chimpanzés em juízo: pessoas, coisas e diferenças”. Horizontes Antropológicos, $17(35): 65-102$

. 2013. "Normas jurídicas e agências não-humanas: o caso dos cães 'perigosos"'. AVÁ, 19: 199-225

. 2014. "Espécies invasoras e fronteiras nacionais: uma reflexão sobre limites do Estado".

Anthropológicas, 24: 103-123.

BLOOM, Harold. 1991. A angústia da influência: uma teoria da poesia. Rio de Janeiro: Imago.

CALMON DE OLIVEIRA, Samantha Brasil. 2006. Sobre homens e cães: um estudo antropológico sobre afetividade, consumo e distinção. Dissertação de Mestrado, Programa de Pós-Graduação em Sociologia e Antropologia, Universidade Federal do Rio de Janeiro.

CASSIDY, Rebecca. 2007. "Introduction: domestication reconsidered". In: Rebecca Cassidy; Molly Mullin (eds.), Where the wild things are now: domestication reconsidered. New York: Berg. pp. 1-25.

DEMELLO, Margo. 2012. "Human-animal studies". In: , Animals and society: an introduction to humananimal studies. New York: Columbia University Press. pp. 3-32.

DESCOLA, Philippe. 1986. La nature domestique: symbolisme et praxis dans l'écologie des Achuar. Paris: Éditions de la Maison des Sciences de l'Homme.

. 1996. "Ecologia e cosmologia”. In: Edna Castro; Florence Pinton (orgs.), Faces do tropic úmido:

conceitos e questões sobre desenvolvimento e meio ambiente. Belém: Cejup, 1996. Pp. 243-261.

2005. Par-delà nature et culture. Paris: Gallimard.

. 2011. "As duas naturezas de Lévi-Strauss". Sociologia \& Antropologia, vol. 01/02: 35-51.

DESCOLA, Philippe \& INGOLD, Tim. 2014. Être au monde: quelle expérience commune? Lyon: PUL.

DIGARD, Jean-Pierre. 1990. L'homme et les animaux domestiques: anthropologie d'une passion. Paris: Fayard. . 1999. Les français et leur animaux: ethnologie d’un phénomène de société. Paris: Fayard. 2012. "Le tournant obscurantiste en anthropologie: de la zoomanie à l'animalisme occidentaux". L'Homme, 2012/3, n. 203-204: 555-578.

ERIKSON, Philippe. 2012. "Animais demais... os xerimbabos no espaço doméstico matis (Amazonas)". Anuário Antropológico, 2012(2): 15-32.

FAUSTO, Carlos. 2004. "Banquete de gente: comensalidade e canibalismo na Amazônia". Mana. Estudos de Antropologia Social, 8(2): 7-44.

FLYNN, Clifton (ed.). 2008. Social creatures: a human and animal studies reader. New York: Lantern Books.

FRANCO, Ana Paula Perota. 2015. Humanidade estendida: a construção dos animais como sujeitos de direitos. Tese de doutorado, Programa de Pós-Graduação em Sociologia e Antropologia Universidade Federal do Rio de Janeiro.

FUDGE, Erica. 2014. Pets. Buenos Aires: Paidós.

HARAWAY, Donna. 2008. When species meet. Minneapolis: University of Minnesota Press.

HARRIS, Marvin. 1976. “Lévi-Strauss et la palourde: réponse à la Conference Gildersleeve de 1972”. L’Homme, 1976/2-3: 5-22.

HELMREICH, Stefan. 2013. Alien ocean: anthropological voyages in microbial seas. Los Angeles: University of California Press. 
HAUDRICOURT, André-Georges. 2013. "Domesticação de animais, cultivo de plantas e tratamento do outro”. Série Tradução, 7. Brasília: UnB.

HURN, Samantha. 2012. Human and other animals: cross-cultural perspectives on human-animal interactions. New York: Pluto Press.

INGOLD, Tim (ed.). 1988. What is an animal? London: Routledge. . 1994. "Humanity and animality". In: (ed.), Companion Encyclopedia of Anthropology. Londres: Routledge. pp. 14-32. 200o. The perception of the environment: essays in livelihood, dwelling and skill. London: Routledge.

KECK, Frédéric. 2010. Un monde grippé. Paris: Flammarion.

KIRKSEY, Eben \& HELMREICH, Stefan. 2010. “The emergence of multispecies ethnography”. Cultural Anthropology, 25(4): 545-576.

LEAL, Natacha Simei. 2016. Nome aos bois: zebus e zebuzeiros em uma pecuária brasileira de leite. São Paulo: Hucitec.

LÉVI-STRAUSS, Claude. 1983a. "Estruturalismo e ecologia". In: , O olhar distanciado. Lisboa: Edições 70. pp. 149-174. . 1983b. "Estruturalismo e empirismo". In: , O olhar distanciado. Lisboa: Edições 70. pp. 175-203.

LEWGOY, Bernardo; SEGATA, Jean. 2016. A persistência da exceção humana. Revista Vivência, 48(1), No prelo.

LEWGOY, Bernardo; SORDI, Caetano; PINTO, Leandra. 2015. "Domesticando o humano: para uma antropologia moral da proteção animal”. Ilha - Revista de Antropologia, v. 17(2): 75-100.

MATOS, Liziane. 2012. Quando a "ajuda é animalitária”: um estudo antropológico sobre sensibilidades e moralidades envolvidas no cuidado e proteção de animais abandonados a partir de Porto Alegre/RS. Dissertação de Mestrado, Programa de Pós-Graduação em Antropologia Social, Universidade Federal do Rio Grande do Sul.

MASTRANGELO, Andrea. 2016. Nombre y rostro, amistad y parentesco: dimensiones de la relación intersubjetiva humano-perro en un área con Leishmaniasis Visceral emergente. Conferência apresentada no ILEA-UFRGS. Mimeo.

PASTORI, Erica. 2012. Perto e longe do coração selvagem: um estudo antropológico sobre animais de estimação em Porto Alegre, Rio Grande do Sul. Dissertação de Mestrado, Programa de Pós-Graduação em Antropologia Social, Universidade Federal do Rio Grande do Sul.

RABINOW, Paul. 1999. "Artificialidade e Iluminismo: da sociobiologia à biossocialidade”. In: João Biehl (org.), Antropologia da razão: ensaios de Paul Rabinow. Rio de Janeiro: Relume-Dumará. pp. 135-158.

ROSALDO, Michele; LAMPHERE, Louise (eds.). 1974. Women, culture and society. Stanford: Stanford University Press.

RUSSEL, Nerissa. 2007. “The domestication of anthropology”. In: Rebecca Cassidy; Molly Mullin (eds.), Where the wild things are now: domestication reconsidered. New York: Berg. pp. 27-48.

SÁ, Guilherme. 2013. No mesmo galho: antropologia de coletivos humanos e animais. Rio de Janeiro: 7 Letras.

SEGATA, Jean. 2012. Nós e os outros humanos, os animais de estimação. Tese de Doutorado, Programa de PósGraduação em Antropologia Social, Universidade Federal de Santa Catarina. . 2015a. "La cosmopolitique de la dépression: biosocialité dans une ethnographie multi-espèces".

Vibrant, 12: 290-320. . 2015b. "Gatos fidalgos, cálculos renais e as humanidades de animais de estimação". Vivência, 44(1), p.85-104. _. 2016a. "A doença socialista e o mosquito dos pobres". Iluminuras, 17(42): 372-389. 
2016b. "Os mosquitos vilões e as casas de ponta de lápis". Trabalho apresentado no Painel To73 -

Relações humano-animal na antropologia, do VI Congresso da Associação Portuguesa de Antropologia. Coimbra - Portugal, 2 a 4 de junho de 2016. Mimeo.

SINGER, Peter. 1975. Animal liberation. New York: HarperCollins Publishers Inc.

SOUZA, Iara Maria de Almeida. 2013. "Vidas experimentais: humanos e roedores no laboratório".

Etnográfica, 17(2): 241-268.

SORDI, Caetano. 2013. De carcaças e máquinas de quatro estômagos: estudo das controvérsias sobre o consumo e

a produção de carne no Brasil. Dissertação de Mestrado, Programa de Pós-Graduação em Antropologia

Social, Universidade Federal do Rio Grande do Sul.

2015. "Quem governa a invasão biológica? Um problema para a antropologia”. Novos Debates: Fórum

de Debates em Antropologia, 2: 270-276.

STRATHERN, Marilyn. 1992. After nature: English kinship in the late twentieth century. Cambridge: Cambridge University Press.

SÜSSEKIND, Felipe. 2014. O rastro da onça: relações entre humanos e animais no Pantanal. Rio de Janeiro: 7

Letras.

TAYLOR, Nik; SIGNAL, Tania (Ed.). 2011. Theorizing animals: re-thinking humanimal relations. Boston: Brill.

TAYLOR, Nik. 2013. Humans, animals and society: an introduction to human-animal studies. New York: Lantern Books.

TEIXEIRA, Ivana dos Santos. 2015. A terapia assistida por animais como uma forma de associação: um estudo antropológico sobre a relação humano-animais na promoção da saúde humana, no Brasil. Tese de doutorado, Programa de Pós-Graduação em Antropologia Social, Universidade Federal do Rio Grande do Sul.

TSING, Anna. 2015. "Margens indomáveis: cogumelos como espécies companheiras". Ilha-Revista de Antropologia, 17(1): 177-201.

VANDER VELDEN, Felipe. 2012. Inquietas companhias: sobre os animais de criação entre os Karitiana. São Paulo: Editora Alameda. . 2015. “Apresentação do dossiê (Animalidades Plurais)”. R@U Revista de Antropologia da UFSCar, 7(1): 7-16.

VANDER VELDEN, Felipe \& BEVILAQUA, Ciméa. 2016. “Introdução”. In: (orgs.), Parentes, vítimas, sujeitos: perspectivas antropológicas sobre relações entre humanos e animais. Curitiba e São Carlos: Editora da UFPR e Editora da UFSCar. pp. 4-37.

VIALLES, Noëlie. 1987. Le sang et la chair: les abattoirs des Pays de l'Adour. Paris: Éditions de la Maison des Sciences de l'Homme.

WILLIS, Roy (ed.). 199o. Signifying animals: human meaning in natural world. London: Routledge.

Jean Segata

Graduate Program in Social Anthropology, Universidade Federal do Rio Grande do Sul, Porto Alegre/RS, Brazil.

jeansegata@ufrgs.br

\section{Bernardo Lewgoy}

Graduate Program in Social Anthropology, Universidade Federal do Rio Grande do Sul, Porto Alegre/RS, Brazil.

mlewgoy.bernardo@gmail.com 